\title{
The impact of surface preparation of wood on the adhesion of certain types of coatings
}

\begin{abstract}
In order to achieve an enhancement of adhesion of specific type of coating to the surface of beech wood (Fagus Sylvatica L.), the optimum substrate preparation system was determined regarding the specific coating formulation. The results showed that lower values of surface roughness parameters can be obtained by the sanding process than by the planning process. These lower values of surface roughness enable higher adhesion of a $2 K$ acrylic-isocyanate coating. In cases where coating is performed with a $1 \mathrm{~K}$ waterborne coating, higher values of adhesion were observed on the surfaces with higher surface roughness. Direct correlation between surface roughness and adhesion of a $2 K$ polyurethane coating was not found. The adhesion between a $1 \mathrm{~K}$ waterborne coating and the wood substrate is primarily based on a mechanical bonding (entanglement), while the adhesion of a $2 \mathrm{~K}$ acrylic-isocyanate coating is primarily based on the other bonding mechanisms.
\end{abstract}

Keywords: Fagus Sylvatica L., sanding, planing, surface roughness, coating formulation, adhesion

\section{INTRODUCTION}

The application of coating onto the wood is preceded by the surface preparation processes, including planing and sanding [1]. The purpose of these processes is to produce a flattened and cleaned surface, as a prerequisite for a quality interaction between the coating and the substrate.

Sanding is a process that is most commonly used in the preparation of a wood surface just before coating [2]. Although the goal is to obtain a smooth surface with no visible defects that will provide a uniform absorption of coatings, abrasive grains that are used in the sanding process are actually tiny knives which cause damage of the wood tissue [2]. These abrasive grains cause tearing of the micro-fibrils in the cell wall, which remain raised from the wood surface [3]. However, the surface becomes more even and more homogeneous after sanding [2] due to the compression of cell walls and clogging of cell lumens with fine sanding dust $[4 ; 5]$. This is confirmed by the SEM images in which the largest anatomical elements of wood are barely visible after sanding [3]. It was found that the sanding process reduces the impact of the anatomical structure of wood on the value of surface roughness [6].

Surfaces formed by the planing process differ greatly from the surfaces obtained by the sanding process [3]. In the planing process wood cells in the surface and sub-surface layers are often deformed or crushed by the cutting blades [7].

Author's address: ${ }^{1}$ University of Belgrade - Faculty of Forestry, Kneza Višeslava 1, Belgrade, Serbia, ${ }^{2}$ Odincovskij lakokrasochnij zavod, Helios group, Transportnij proezd 3, Odincovo, Russia

Received for Publication: 22. 12. 2013.

Accepted for Publication: 19. 02. 2014.
Resistance to penetration of cutting edge of a blade into a wood tissue depends on size and shape of cells, and the thickness of cell wall which determines their strength [8]. It was found that the use of sharp knives is the key factor in preventing the deformation of the wood tissue cells in the surface layer [9] and obtaining of a homogeneous and smooth surface with various anatomical elements that are visible under the SEM microscope [5].

The quality of wood can be evaluated on the basis of its surface roughness. There is a large number of parameters of the sanding process that affect the surface roughness of wood, including: grit size, feed speed, type of abrasive material, sanding direction [3], sanding speed and cutting depth $[1,10]$. In addition to wood species [11, 12], feed speed and cutting depth are among the most important parameters that determine the quality of a planed surface [7]. In addition, rank angle [11] and the cutting direction relative to the direction of wood grains [12] may have an impact on the surface roughness after planing.

A small number of studies have investigated the relationship between surface roughness and the properties of the cured coating on a wood surface. Although low surface roughness is a precondition for the achievement of a smooth coated surface without defects, it does not guarantee a high adhesion between the coating and the substrate. The crushed and deformed wood cells in the surface and sub-surface layers can make these layers behave as mechanically weak boundary layers at the interface of the coating and the substrate [3]. The mechanical entanglement of a coating to a substrate is directly related to the penetration of the coating [4]. In addition to mechanical bonding, other mechanisms involved in adhe- 
sion may be promoted by the penetration of the coating, due to an increase in the contact area between the coating and the cell wall [4]. It was shown that the penetration of coating after sanding is lower or completely disabled due to the deformation of cells and clogging of wood capillaries with fine dust [9]. The damages in the surface and sub-surface layers that could reduce the penetration of the coating [4] often occur in the process of planing, as well. A rough surface leads to an irregular film thickness of the coating, which can also affect the value of adhesion [5].

This paper investigates the impact of the surface roughness obtained by the planing and sanding processes on the adhesion of a coating with a specific formulation. The mechanism of adhesion will be affected by the coating formulation. Therefore, the objective of this research is to determine the optimum surface preparation system from the aspect of adhesion of certain types of coatings.

\section{MATERIALS AND METHODS}

\subsection{The selection and preparation of a substrate}

This research used samples of beech wood (Fagus Silvatica L.) with $500 \times 100 \times 50 \mathrm{~mm}$ dimensions. The samples were cut from the boards whose moisture content was below $12 \%$. After cutting into the required dimensions, the samples were divided into groups and surface preparation was performed. The samples from groups I to VI were prepared by the planing process, while the samples from groups $\mathrm{VI}$ to $\mathrm{XV}$ were sanded in order to obtain a flat and smooth surface.

The planing was performed on the planer machine Model S63 of the manufacturer SCM Group. The machine was equipped with a $120 \mathrm{~mm}$ diameter cutter head, with four $630 \mathrm{~mm}$ long blades. The number of revolutions was $2850 \mathrm{rpm}$, and the cutting depth was $3 \mathrm{~mm}$. The maximum quality of the surface of beech wood samples achieved by planing is obtained at the specified value of cutting depth [12]. Two feed speeds were used in the planing process in order to determine the impact of the machining parameters on the surface roughness and the adhesion of the coating. The cutting speed was $17.9 \mathrm{~m} / \mathrm{s}$, while the feed speed amounted to $6.6 \mathrm{~m} / \mathrm{min}$ (for samples of groups I, II and III) and $13.3 \mathrm{~m} / \mathrm{min}$ (for samples of groups IV, V and VI).

The sanding was performed on a narrow-belt sanding machine with manual control Model L 55 of the manufacturer Minimax. The sanding speed was $13 \mathrm{~m} / \mathrm{s}$, and the pressure of sanding was achieved by lowering the pedal onto the sanding belt. In all samples, the direction of machining in the last stage of sanding corresponded with the direction of wood grains. Table 1 provides the grit sizes and sanding directions relative to the direction of wood grains, by sanding stages for specific sanding systems.

Table 1 - Parameters of the sanding system by stages

\begin{tabular}{|c|c|c|c|}
\hline $\begin{array}{c}\text { Sanding } \\
\text { system }\end{array}$ & \multicolumn{3}{|c|}{$\begin{array}{c}\text { Grit size and direction of sanding in } \\
\text { relation to wood grain orientation }\end{array}$} \\
\hline 1 & $\begin{array}{c}\text { First } \\
\text { stage }\end{array}$ & $\begin{array}{c}\text { Second } \\
\text { stage }\end{array}$ & Third stage \\
\hline 2 & $100 / /$ & $/$ & $\perp$ \\
\hline 3 & $100 \perp$ & $150 / /$ & \\
\hline 4 & $100 / /$ & $150 \perp$ & $/ /$ \\
\hline
\end{tabular}

\subsection{Surface roughness measurement}

The characterization of the geometric state of the samples' surface was performed by determining the surface roughness parameters $R_{a}, R_{t}$ and $R_{c}$ in the "M" system. These parameters belong to the amplitude parameters, which describe height properties of a deviation on the observed profile length. Although surface roughness is commonly expressed by the parameter $R_{a}$, the introduction of additional parameters is aimed at a more precise determination of the height properties of a roughness profile. The definitions of the measured parameters are given in Table 2.

Table 2 - Definitions of the surface roughness parameters in the $M$ system according to ISO 4287

\begin{tabular}{|c|l|}
\hline Parameter & \multicolumn{1}{|c|}{ Definition } \\
\hline $\mathrm{Ra}$ & $\begin{array}{l}\text { Arithmetic mean deviation of the } \\
\text { assessed profile }\end{array}$ \\
\hline $\mathrm{Rt}$ & Total height of profile \\
\hline $\mathrm{Rc}$ & Mean height of profile elements \\
\hline
\end{tabular}

The contact surface profiler Talysurf- 6 of the manufacturer Rank Taylor Hobson was used for the determination of surface roughness parameters. The measurement of roughness is based on the horizontal movement of a stylus with a diamond tip along the test surface. The driving force acting upon the stylus with a maximum of $0.5 \mathrm{~N}$ provides a constant direct contact of the stylus and the test surface. Vertical movement of the stylus is converted into electrical impulses, which are filtered and amplified. The calculation of surface roughness parameters is performed using the microprocessor, on the basis of the collected electrical impulses.

The roughness measurement was performed at three positions on ten samples from each prepa- 
ration system, across the grain orientation. The separation of roughness from other types of deviations was performed by choosing the cut-off length of $0.8 \mathrm{~mm}$.

\subsection{Coating of the samples}

In order to determine the impact of the formulation of coating on the values of adhesion, three types of coatings were applied to the samples after their preparation, including: a $2 \mathrm{~K}$ polyurethane coating, a $2 \mathrm{~K}$ acrylic-isocyanate coating and a $1 \mathrm{~K}$ waterborne coating based on acrylic resins. All samples were coated by applying one primer and one topcoat layer. The parameters of the coatings are given in Table 3 .

Table 3 - Parameters of coatings for application

\begin{tabular}{|l|c|c|c|c|c|c|}
\hline \multirow{2}{*}{ Type of coating } & \multicolumn{2}{|c|}{ 2K polyurethane coating } & \multicolumn{2}{c|}{ 2K acrylic-isocyanate coating } & \multicolumn{2}{c|}{ 1K Waterborne coating } \\
\cline { 2 - 7 } & Primer & Topcoat & Primer & Topcoat & Primer & Topcoat \\
\hline Trade name & Dugapur OP & Dugapur PP 40 & Dugakril OP & $\begin{array}{c}\text { Dugakril PP } \\
40\end{array}$ & $\begin{array}{c}\text { AU 466/00, } \\
\text { Sayerlack }\end{array}$ & $\begin{array}{c}\text { AZ 5730/00, } \\
\text { Sayerlack }\end{array}$ \\
\hline Density $\left(\mathrm{g} / \mathrm{cm}^{3}\right)$ & $0.97 \pm 0.01$ & $0.94 \pm 0.01$ & $0.89 \pm 0.01$ & $0.98 \pm 0.01$ & $1.01 \pm 0.03$ & $1.02 \pm 0.03$ \\
\hline $\begin{array}{l}\text { Viscosity }-\mathrm{F} / 4, \\
20^{0} \mathrm{C}(\mathrm{s})\end{array}$ & $46-65$ & $20-23$ & $27-33$ & $35-45$ & $32-36$ & $30-36$ \\
\hline Solid content (\%) & $37 \pm 1$ & $27 \pm 1$ & $34 \pm 1$ & $35 \pm 1$ & $35 \pm 1$ & $35 \pm 1$ \\
\hline $\begin{array}{l}\text { Ratio of } \\
\text { components }\end{array}$ \\
\hline $\begin{array}{l}\text { Thinner in } \\
\text { mixture }(\%)\end{array}$ & $2: 1$ & & $5: 1$ & & $/$ \\
\hline
\end{tabular}

The addition of the appropriate amount of thinner was tasked with setting the coating viscosity to a value of $22 \mathrm{~s}\left(\mathrm{~F} 4,20^{\circ} \mathrm{C}\right)$ that is needed for air spraying. The spraying was carried out in an area protected from dust, under controlled conditions of the working environment $\left(\mathrm{t}=21^{\circ} \mathrm{C}\right.$, $\varphi=60 \%$ ), in order to reduce the possibility of coating defects. All layers of coatings were applied by air spraying at the application rate of $150 \mathrm{~g} / \mathrm{m}^{2}$. The nozzle diameter was $1.6 \mathrm{~mm}$ and the air pressure was 3 bar. The spraying gun was set at the distance of $250 \mathrm{~mm}$ from the workpiece.

Table 4 provides the systems of preparation and coating of specific sample groups.

Table 4 - Preparation and coating of specific sample groups

\begin{tabular}{|l|c|c|c|c|}
\hline \multirow{2}{*}{$\begin{array}{c}\text { Type of preparation } \\
\text { process }\end{array}$} & $\begin{array}{c}\text { Processing } \\
\text { system }\end{array}$ & $\begin{array}{c}\text { 2K polyurethane } \\
\text { coating }\end{array}$ & $\begin{array}{c}\text { 2K acrylic-isocyanate } \\
\text { coating }\end{array}$ & $\begin{array}{c}\text { 1K Waterborne } \\
\text { coating }\end{array}$ \\
\cline { 2 - 5 } Planing & system 1 & $\mathrm{I}$ & $\mathrm{II}$ & $\mathrm{III}$ \\
\hline \multirow{3}{*}{ Sanding } & system 2 & $\mathrm{IV}$ & $\mathrm{V}$ & $\mathrm{VI}$ \\
& system 1 & VII & VIII & $\mathrm{IX}$ \\
\cline { 2 - 5 } & system 2 & $\mathrm{X}$ & $\mathrm{XI}$ & $\mathrm{XII}$ \\
\cline { 2 - 5 } & system 3 & $\mathrm{XIII}$ & $\mathrm{XIV}$ & $\mathrm{XV}$ \\
\hline
\end{tabular}

The curing of the coatings was carried out under controlled conditions of the working environment, at the ambient temperature of $20^{\circ} \mathrm{C}$ and relative humidity of $\varphi=65 \%$.

\subsection{Adhesion of a coating}

The measurement of the adhesion of a coating was performed by the pull-off test in accordance with the standard EN ISO 4624. This method involves measuring of the maximum tensile strength of a coating that leads to the detachment of cylinders from the coated surface. Iron cylinders with $20-\mathrm{mm}$ diameters were glued to the coated surface with a $2 \mathrm{~K}$ epoxy adhesive. After curing of the adhesive (after $48 \mathrm{~h}$ ) the samples were placed in a testing device (manufacturer Amstell). The pull-off test involves withdrawal of cylinders upwards vertically in the opposite direction from the position of the sample. The constancy of the speed of detachment is enabled by a mechanized movement using an electric motor.

The measurement of adhesion of the coating was performed 7 days after the coating of the samples. Ten measurements were performed on samples from each group (see Table 4).

\section{RESULTS}

Figure 1 shows the impact of the applied system of surface preparation on the values of surface roughness parameters $R_{a}, R_{t}$ and $R_{c}$. 


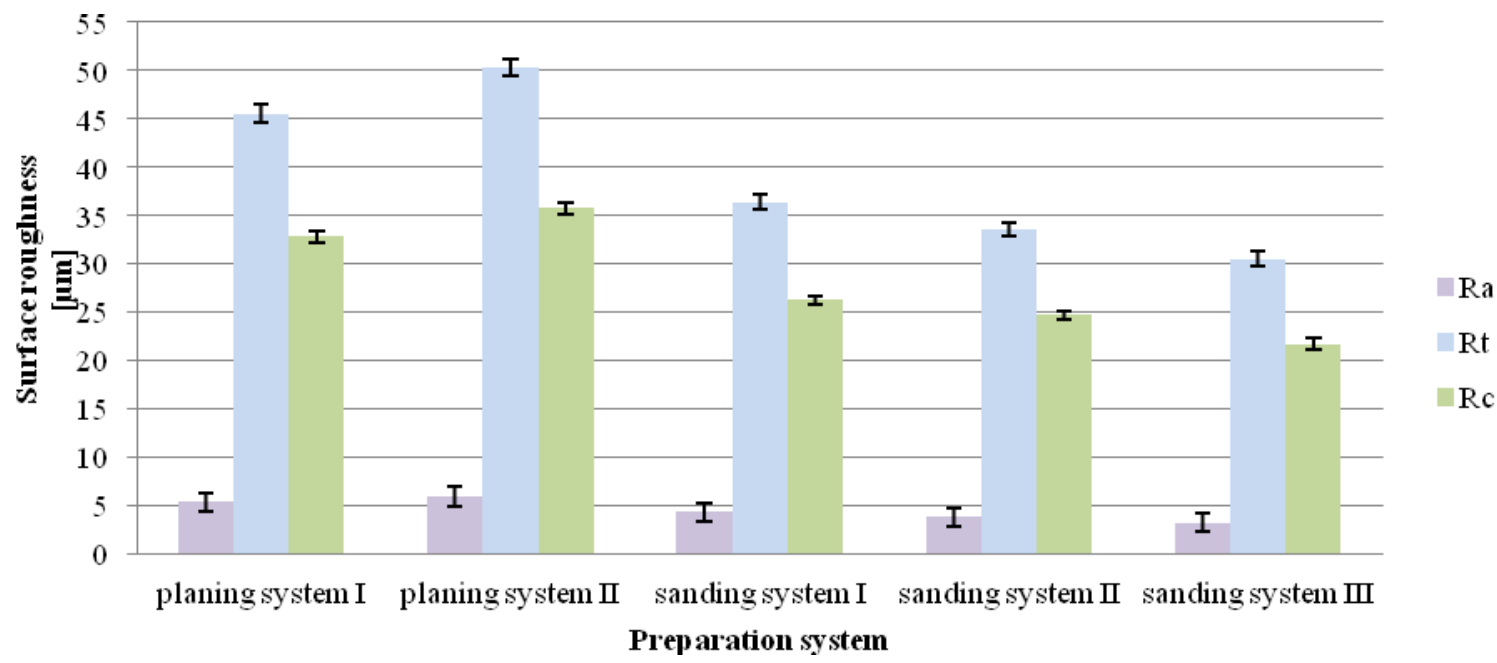

Figure 1 - The impact of surface preparation on the surface roughness parameters $R_{a}, R_{t}$ and $R_{c}$ (with the standard error of the mean).

The obtained results showed that the highest values of surface roughness were measured in the samples that were processed by planing with the feed speed of $13.3 \mathrm{~m} / \mathrm{min}$. The samples that were processed by planing at a lower feed speed (6.6 $\mathrm{m} / \mathrm{min}$ ) revealed lower values of surface roughness parameters. However, the obtained values were higher than the values of surface roughness parameters obtained by sanding. The above result is consistent with the technological organization of the wood preparation processes, as wood is usually sanded before coating.

Figure 2 shows the value of adhesion in relation to the selected system of surface preparation and the coating formulation.

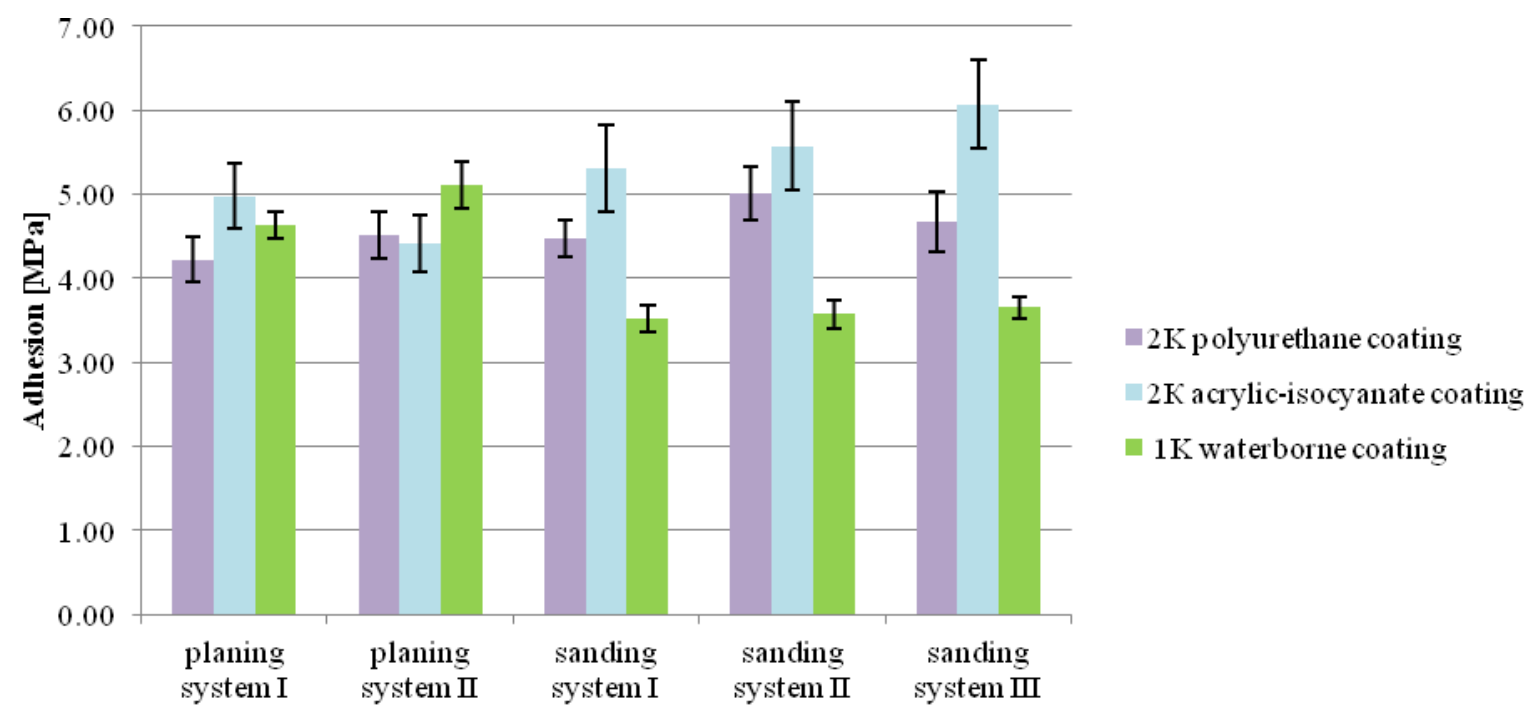

Preparation system

Figure 2 - The impact of surface preparation on the adhesion of $2 K$ polyurethane, $2 K$ acryl-isocyanate and $1 \mathrm{~K}$ waterborne coatings (with the standard error of the mean).

A regression analysis was performed in order to investigate the existence of a linear dependence between surface roughness, expressed by the parameter $R_{a}$, and adhesion of the coating. Figure 3 shows the impact of the value of parameter $R_{a}$ on the value of adhesion of $2 \mathrm{~K}$ acrylic-isocyanate (3.a) and $1 \mathrm{~K}$ waterborne coatings (3.b). The high values of the coefficient of determination for the $2 \mathrm{~K}$ acrylicisocyanate and $1 \mathrm{~K}$ waterborne coatings mean that regression line adequately represents the measured results. On the basis of the standard errors of slope, the value of statistics of the t-test 
was determined. It shows that there is a linear dependence between the parameter $R_{a}$ and the adhesion of the coating at the level of confidence of 0.05 . In the case of the $2 \mathrm{~K}$ polyurethane coating,

a)

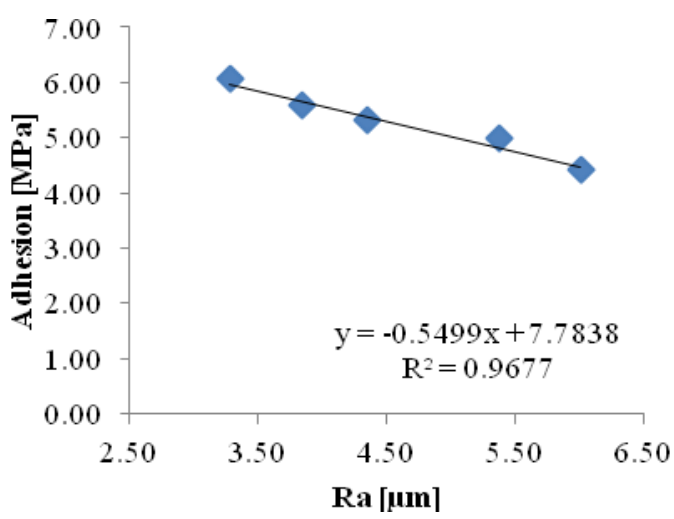

Figure 3 - The impact of the roughness parameter $R_{a}$ on the adhesion of the a) $2 K$ acrylic-isocyanate coating and $b) 1 \mathrm{~K}$ waterborne coating.

\section{DISCUSSION}

The impact of feed speed in planning process on the surface roughness value is consistent with the results of other authors $[1 ; 8 ; 13 ; 14]$. On the other hand, privious study showed [11] to the conclusion that with the increase of feed speed, the quality of the surface of beech wood and other examined species increases, expressed by the parameters of surface roughness $R_{z}$. The above inconsistency leads to the conclusion that it is necessary to include additional parameters of planing, such as cutting depth, into the assessment of the impact of feed speed on the parameters of surface roughness.

The comparison of different sanding systems showed that surface roughness decreases with an increasing grit size in the last stage of sanding, which is in compliance with the results obtained by other authors [3; 10;13-15]. This confirms that surface defects can be reduced by using abrasive grains of smaller sizes [3].

Tests have shown that, in general, lower values of surface roughness can be obtained by sanding [13]. However, the obtained results are not in agreement with the results of comparisons of the parameter $R_{a}$ on the samples of beech and maple wood after planing and sanding, where lower values of roughness were achieved by planing compared to sanding ([14] and [16], respectively). This conclusion requires introduction of the parameter of tool sharpness into the assessment of the impact of surface processing on surface roughness, since it was found that the use of dull knives can lead to the formation of a compact the t-test showed that there was no linear dependence between the parameter $R_{a}$ and the adhesion of the coating.

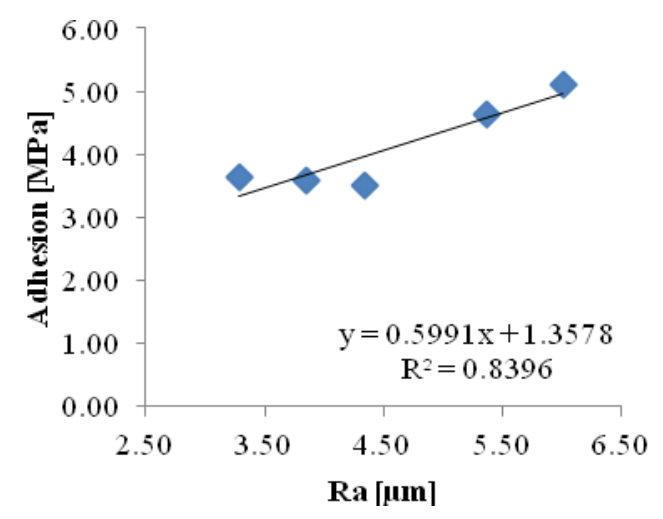

b) surface layer of approximately uniform thickness, as opposed to the sporadic defects in the surface layer occurring after sanding [3].

Linear regression equations show that in the case of the $2 \mathrm{~K}$ acrylic-isocyanate coating there is a direct dependency, and that the increase in surface roughness, expressed by the value of the parameter $R_{a}$, leads to a decrease in the adhesive bonding of the coating and the substrate. In the case of the $1 \mathrm{~K}$ waterborne coating, linear regression equation shows that an enhancement of roughness leads to an increased adhesion of the coating. It can be concluded that the adhesion between a $1 \mathrm{~K}$ waterborne coating and the substrate is primarily based on a mechanical bonding (entanglement), while the adhesion of a $2 \mathrm{~K}$ acrylicisocyanate coating is primarily based on other bonding mechanisms (e.g. chemical bonding of the coating and wood). Both chemical and mechanical bonding mechanisms participate in the adhesion of a $2 \mathrm{~K}$ polyurethane coating. The effect of mechanical bonding is particularly pronounced in the case of waterborne coatings due to the swelling of fibers in the surface layer of wood in contact with water. Waterborne coatings are generally characterized by a weak adhesion in comparison to the coatings based on organic solvents (on average by $30 \%$ lower value than the value of adhesion of a polyurethane coating on beech wood samples for a wood moisture content of 8-12 \%, [17]). The results of this study have shown that an increase in the value of adhesion by $29.35 \%$ (planing system I) and by $42.53 \%$ (planing system II), can be achieved through an increase in surface rough- 
ness. The enhancement of the value of adhesion that is achieved by increasing surface roughness confirms the domination of the mechanical mechanism of bonding for this type of coating.

The high values of adhesion of a $2 \mathrm{~K}$ polyurethane coating on the samples of Eastern beech (Fagus orientalis L.), oak (Quercus petraea L.) and Scots pine (Pinus sylvestris L.) wood are explained by the participation of chemical components in the surface layer of wood in the reactions of polymerization [17]. The chemical reactions of beech wood and polyurethane coatings were evaluated through an increase in the heat effect during the curing of the polyurethane coating in the presence of wood, by the DSC method [18]. Wood hydroxyl groups can react with isocyanate groups of the polyurethane coating [19]. Since $2 \mathrm{~K}$ acrylic-isocyanate coatings cure by the reaction of polymerization between the hydroxyl groups in resin and the isocyanate component, the above conclusion can also be accepted for this type of coating. The value of adhesion of a $2 \mathrm{~K}$ polyurethane coating on beech wood samples [17] was by $8-11 \%$ higher than the values measured in this study, for the same system of surface preparation (sanding system I). The value of adhesion of the $1 \mathrm{~K}$ waterborne coating in this study is by $2-7 \%$ higher than the value of adhesion of same type of coating in above mentioned research, for the same wood species and sanding system (sanding system I).

On the basis of the values of adhesion of $1 \mathrm{~K}$ waterborne coatings on samples prepared by different sanding systems, the number of stages of sanding can be reduce in order to decrease production cost without an impact on adhesion. This is in agreement with results of previous research where two-stage sanding program resulted in similar results of adhesion to that of three-stage sanding program [16]. Furthermore, "deep damages" in the wood tissue that can affect the quality of surface after application of waterborne coating did not appear at the maximum values of machining parameters: feed speed of $9.1 \mathrm{~m} / \mathrm{min}$ and cutting depth of $9.5 \mathrm{~mm}$ [20]. Accordingly, planning can be recommended as preparation process of wood before coating with waterborne coating.

\section{CONCLUSIONS}

The results of this study show that lower values of surface roughness are obtained when surface preparation is performed by sanding of wood as opposed to planing. The surface roughness of beech wood (expressed by the roughness parameter $R_{a}$ ) decreases with an increasing grit size in the last stage of sanding. An increase in the feed speed of the planing process has a negative impact on the value of surface roughness (expressed by the roughness parameter $R_{a}$ ).

In order to achieve higher values of adhesion, surface preparation should be performed by sanding in two stages (100-150 grit), when the wood is to be coated with a $2 \mathrm{~K}$ polyurethane coating or in three stages (100-150-180 grit), when the surface is to be coated with a $2 \mathrm{~K}$ acrylicisocyanate coating. On the other hand, prior to the application of a waterborne coating, surface preparation should be performed by planing at a lower feed speed ( $u=13.3 \mathrm{~m} / \mathrm{min}$ ).

\section{Acknowledgment}

This paper was realized as a part of the project Establishment of Wood Plantations Intended for Afforestation of Serbia (31041) financed by the Ministry of Education and Science of the Republic of Serbia within the framework Technological development for the period 2011-2014. We would like to acknowledge Prof. Ksenija Radotić HadžiManić from Institute for Multidisciplinary Research, University of Belgrade, and Prof. Miodrag Mićić from Cerritos College, Norwalk, $C A$, and MP Biomedicals, Santa Ana, CA, for their review and help.

\section{REFERENCES}

[1] Coelho, C.L., Carvalho, L.M.H., Martins, J.M., Costa, C.A.V., Masson, D, Méausoone, P-J., (2008): Method for evaluating the influence of wood machining conditions on the objective characterization and subjective perception of a finished surface, Wood Sci Technol 42(3): 181-195.

[2] Porankiewicz, B., Wieloch, G., (2008): Sanding of Fagus Silvatica L. Wood Perpendicularly to Grains, Bioresources 3(3): 684-700.

[3] de Moura, L.F., Hernández, R.E., (2006): Effects of abrasive mineral, grit size and feed speed on the quality of sanded surfaces of sugar maple wood, Wood Sci Technol 40(6): 517-530.

[4] de Meijer, M., Thurich, K., Militz, H., (1998): Comparative study on penetration characteristics of modern wood coatings, Wood Science and Technology 32 (5): 347-365.

[5] Arnold, M., (2010): Planing and Sanding of Wood Surfaces - Effects on Surface Properties and Coating Performance, "PRA's $7^{\text {th }}$ International Woodcoatings Congress", "Reducing the Environmental Footprint", pp 1-12.

[6] Richter, K., Feist, W.C., Knaebe, M.T., (1995): The effect of surface roughness on the performance of finishes. Part 1. Roughness characterization and stain performance, Forest Products Journal 45 (7/8): 91-97.

[7] Hernández, R., Cool, J., (2008): Effects of cutting parameters on surface quality of paper birch wood machined across the grain with two planing techniques, Holz Roh Werkst 66(2): 147-154. 
[8] Škaljić, N., Beljo Lučić, R., Čavlović, A., Obućina, M., (2009): Effect of Feed Speed and Wood Species on Roughness of Machined Surface, Drvna industrija 60 (4): 229-234.

[9] de Meijer, M., (2004): A review of interfacial aspects in wood coatings: wetting, surface energy, substrate penetration and adhesion, COST E18.

[10] Salcă, E-A., Hiziroglu, S., (2012): Analysis Of Surface Roughness Of Black Alder As Function Of Various Processing Parameters, Pro Ligno 8(2): 68-79.

[11] Malkoçoğlu, A., (2007): Machining properties and surface roughness of various wood species planed in different conditions, Building and Environment 42(7): 2562-2567.

[12] Aguilera, A., Martin, P., (2001): Machining qualification of solid wood of Fagus silvatica L. and Picea excelsa L.: cutting forces, power requirements and surface roughness, Holz als Roh-und Werkstoff, 59(6): 483-488.

[13] Đorđević, B., (2002): Kvalitet površinske obrade drveta u zavisnosti od načina pripreme podloge i primenjenog sistema zaštite (Quality of wood surface finishing, depending on the substrate preparation method and the applied system for protection), master's thesis, University of Belgrade, Faculty of Forestry.

[14] Džinčić, I., (2005): The influence of the machining parameters by molding and sanding on quality of beech wood surface, Wood processing 9-10: 18-22.
[15] Cool, J., Hernández, R., (2011): Improving the Sanding Process of Black Spruce Wood for Surface Quality and Water-Based Coating Adhesion, Forest Products Journal 61(5): 372-380.

[16] de Moura, L.F., Hernández, R., (2005): Evaluation of varnish coating performance for two surfacing methods on sugar maple wood, Wood and Fiber Science, 37(2): 355-366.

[17] Sönmez, M., Budakçi, M., Bayram, M., (2011): Effect of wood moisture content on adhesion of varnish coatings, Scientific Research and Essay 4: 14321437.

[18] Jaić, M., Živanović, R., Miljković, J., Filipović, J., Petrović-Đakov, D., (1996): Investigation of the interaction between a polyurethane coating and the surface of some hardwood species, J.Serb.Chem.Soc 61(3): 197-205.

[19] Jaić, M., Živanović, R. (1997): The influence of the ratio of the polyurethane coating components on the quality of finished wood surface, Holz als Roh-und Werkstoff 55, Springer-Verlag, (319-322)

[20] Carrano, A.L., Taylor J.B., Lemaster R.L., (2004): Machining-induced subsurface damage of wood, Forest Products Journal 54(1): 85-91.

[21] EN ISO 4624, (2002): Paints and varnishes. Pull-off test for adhesion.

[22] ISO 4287, (1997): Geometrical Product Specifications (GPS). Surface texture: Profile method. Terms definitions and surface texture parameters.

\section{IZVOD}

\section{UTICAJ POSTUPKA PRIPREME POVRŠINE DRVETA NA ADHEZIJU ODREĐENIH VRSTA PREMAZA}

Cilj ovoga rada je bio utvrđivanje optimalnog sistema pripreme podloge bukovog drveta (Fagus Silvatica L.) u cilju postizanja viših vrednosti adhezije pojedinih vrsta premaza. Rezultati ispitivanja su pokazali da se obradom drveta brušenjem dobijaju niže vrednosti parametara hrapavosti u površinskom sloju u odnosu obradu drveta glodanjem. Smanjivanje hrapavosti podloge u površinskom sloju rezultovalo je porastom adhezije $2 \mathrm{~K}$ akril - izocijanatog premaza. Kada je lakiranje vršeno primenom $1 \mathrm{~K}$ vodorazredivog premaza, više vrednosti adhezije su zabeležene na površinama sa većom hrapavosti podloge. Direktna veza između hrapavosti podloge $i$ adhezije $2 \mathrm{~K}$ poliuretanskog premaza nije pronađena. Mehanizam adhezije između $1 \mathrm{~K}$ vodorazredivog premaza i podloge drveta je prvenstveno zasnovan na mehaničkom vezivanju, dok je adhezija $2 \mathrm{~K}$ akril - izocijanatog premaza i drveta zasnovana na drugim mehanizmima vezivanja.

Ključne reči: Fagus silvatica L., brušenje, glodanje, hrapavost površine, formulacija premaza, adhezija

Originalni naučni rad

Primljeno za publikovanje: 22. 12. 2013.

Prihvaćeno za publikovanje:19. 02. 2014. 